Research Article

(c) 2022 Elsa Vula. This is an open access article licensed under the Creative Commons Attribution-NonCommercial 4.o International License (https://creativecommons.org/licenses/by-nc/4.o/)

\title{
Empirical Research of Translating Albanian Literary Text into English by Albanian EFL Students
}

\author{
Elsa Vula \\ Assistant Professor, \\ Department of English Language - Translation and Interpretation, \\ Faculty of Philology, University of Gjakova "Fehmi Agani", \\ Gjakovë, Kosovo
}

DOI: https://doi.org/10.36941/jesr-2022-0057

\begin{abstract}
Literary translation is a type of translation, which requires a great commitment in realizing it. The differences that may be shared by the SL and TL make translation as a process a complicated and challenging one, especially when it comes to literary text translation. The messages, emotions and culture that the literature of a language shares sometimes seem almost difficult to be passed from one language to another one. This is a consequence of differences that the two different languages share in their construction and in their culture. This paper has been focused on the problems of equivalence while dealing with Albanian literary text translation to English, carried out by Albanian university students who study English Language and Literature. Empirical and qualitative are the research methods that have been used in this scientific paper. All these methods have verified the three hypotheses of this research as well as have found the answers to the questions on this research. In addition, the results reached from the three aforementioned research methods have helped in achieving the objectives and aims of this paper.The corpora that has been used in this research is the Albanian literary texts: "Ajkuna qan Omerin" from Kangë Kreshnikësh (Kreshink's Songs). The text has been translated by Albanian students that study English Language and Literature at the University of Gjakova "Fehmi Agani", Faculty of Philology, department of English language and Literature and at University of Prizren "Ukshin Hoti", Faculty of Philology, department of English language and Literature. The translated versions were used as primary source materials for analysis. Another instrument used in this research is the questionnaire, consisting of two open-ended questions. One question aimed at identifying difficulties or challenges that students might have or face during their translation, whereas the second question asked them about the solutions that they might find when dealing with difficulties or challenges during Albanian literary text translation. Thus, the problems of equivalence during Albanian literary texts translation have been identified based on the analysis of students' translation, and on their responses regarding difficulties or challenges that they faced or had during text translations. The work presents the most common strategies used by Albanian students during the process of literary text translation from Albanian into English.
\end{abstract}

Keywords: Albanian language, English language, equivalence, translation, methods of translation

\section{Introduction and Literature Review}

Translation has existed for many centuries as a process which makes a cultural and linguistic transfer from a source language into a target one. Actually translation can be considered as a way of 
communication across different languages and cultures. It is generally known that no two languages of the world share more similarities than differences in their structure or culture. Furthermore, the problem arises when translators or students deal with translation of literary texts from one language into another one, because before getting into literary translation translators or students should take into accounts difficulties or challenges they have to cope with in order to provide an equivalent translation. So, since languages have different phonetic, grammar, syntax and vocabulary structures, the equivalence is seen as a very crucial element in translation, especially in literary texts translation. The "equivalence" as a term became an essential feature of translation theory in the 1960s and 1970s. Many scholars have been dealing with it, like Vineay and Darbelnet (1958), Jackobson (1959), Nida and Taber (1969), Koller (1979), NewMark (1981), Baker (1992/2018), and Pym (2010) (as citied on Panou, 2013).

Considered as a very important element in translation and a hard one to be achieved when translating from a source language into a target one, equivalence cause many difficulties and challenges to many translators, especially to Albanian translators or Albanian students who study English language and literature. Being an English teaching assistant for almost five years now and teaching the Theory of Translation course I have noticed that students have a lot of difficulties, especially when they do literary translation from Albanian to English. Even though Albanian is students' first language they have great challenges in translating Albanian idioms or proverbs in English. In addition, a variety of differences in lexicology and in culture between Albanian and English increase the problems of equivalence.

Literary text translation is much more complicated than non-literary text translation, because the translator in such text translation, has to have a background knowledge on a particular literary text. In addition, he/she should know the culture, i.e., beliefs, values, attitudes, etc., and morals of speakers of both languages in order to make an equivalent translation from the source language into the target one.

Hurry (2014) states that in translation we have to have cultural background knowledge in order to translate properly, especially in literary translation because the success in translation does not rely only on understanding its text structure but it is determined by the knowledge of the cultural terms. Whereas Cook (2013) claims that each language of the world shares some conventions, beliefs, and values which pertain in a specific society that can differ from the others, so trying to translate such elements of a source language into a target language requires an art of doing it.

On the other hand, Gibová (2014) states that all literary translators have their individual styles i.e. characteristic modes of expressions, which they consciously or unconsciously display. More specifically literary translation customarily splits into translation of poetry, prose, and translation of drama, reflecting three majors stands of literary texts. In the study upon the tested students' performance in the in-class translation of an unseen literary text excerpt from English into Slovak, Gibová (2014), in her scientific paper "The dark side of Literary Translation: An analysis of Translation Trainees' Performance" found that all tested students encountered problems in finding an appropriate equivalent translation for English adjectives, struggled with the disambiguation of more complex syntactic structures, as well as having difficulties in translating cultural references. She adds that improvements should be done in theoretical preparation focusing on morphology, lexicology, and knowledge of the culture of English- speaking countries.

Albanian and English languages have a variety of differences in their structure, which reflect in a variety of differences in their culture. Their differences in all grammatical levels cause many challenges or problems to Albanian students who study English language, especially when dealing with Albanian literary text translation into English as a target language. Firstly, the Albanian grammar is much more elaborated and consists of a higher number of elements than English language. The large number of Albanian language verb moods and tenses and their lack in English language result in non-equivalence and culture losses during the Albanian literary text translation into English language. So the issue of transferring the equivalence or the sameness from Albanian literary text into English language sometimes is a huge challenge for Albanian students. 
In the analysis of extracts from Graham Greene's novel "The Comedians" translated in Albanian language, Tanku (2013) in his study "Overview of translation process and equivalence in Albanian literary translations" shows samples of two mostly used strategies in order to achieve equivalence, such as: transposition, and adaptations like:

"with a note of reproof" given as "si me qortim",

"with his hands folded", given as "me duart kryq",

"but had he" given to the context situation as "por ai për të vetin ta gëzonte vallë?",

"He looked at me with grave attention" as "Më vështroi me vëmendje rëndë-rëndë".

"He go away." given as "Ka ik."

"He stay all the same" as "Prapëseprapë rri"

"He very sick man" as "Po ai shumë sëmurë"

He says "I be old man" as "Unë plak njeri"- tha

He claims that when doing literary translations in Albanian most of the translators prefer cultural approaches as they want their work to be read by as many people as possible. In contrast there are many translators who use many unnecessary borrowings and many times lose the function of the source text into the target language (Tanku 2013).

As mentioned previously the issue of equivalence transfer is considered a crucial and major feature of the translation process, but it cannot be considered as the only one. The second issue or challenge that Albanian students might face during the Albanian literary text translation is the cultural translation of a source text into English language. According to Masri (2009) cultural translation involves translation of linguistic structures, as a part of language in which the translator should take into account not only the equivalence of meaning but also investigates levels of content, context, semantics, and pragmatics.

Guerra (2012) states:

One of the problems a translator can face arises from the fact that some words or phrases denoting objects, facts, phenomena, etc... are so deeply rooted in their source culture (SC) and so specific (and perhaps exclusive or unique) to the culture that produced them, that they have no equivalent in the target culture (TC), be it because they are unknown, or because they are not yet codified in the target language (TL). (pg.4)

In addition, such differences in culture among source language and target language may create complications more than do differences in structure (Nida pg.130, as citied in Guerra, 2012). Gorjan (1970) holds the same view and states that translators can strive to come as close to the original as possible, but they can or will never achieve a complete identity in their translations.

The cultural expressions of a language comprise linguistic cultural elements (idioms, proverbs, metaphor, and collocations) which sometimes cannot be given the equivalent translation and often can lead to having nonequivalence in the target language. Many Albanian idioms or proverbs are difficult to transmit into a coherent and equivalent translation in English because of the differences in cultural elements. Because of this they may end up in losing their function and the role in the target language.

In the article "Comprehension and Interpretation of English and Albanian fixed expressions" by Koça and Jashari (2013) it states that the fixed expressions or idioms are hard to be translated in a target language since they require a sound background knowledge as well as equivalence in order to convey the same meaning in a target language. Their study was conducted with EFL students from university of Korça.

Generally, based on the data of their research it was discovered that students found it easy to translate those idioms that had explanations and definitions which clarified the meaning of the idioms rather than those idioms not accompanied with any explanations (Koça\&Jashari, 2013, pg.323).

For example: An idiom given by its definition:

"To catch someone red-handed" means to "discover someone while they are doing something 
bad or illegal" (Cambridge Dictionary).

This idiom was translated almost by all students correctly because they had a definition of this one and most of the answers were like:

Albanian translation "Të kapësh dikë me presh në dorë"

Generally, Koça and Jashari (2013) conclude that "the comprehension and interpretation of the unknown idiomatic expressions is difficult because of their special features, out of context, their meaning is difficult to be detected both in the native and foreign language" (pg.324).

The published research paper "Comparative analysis of English and Albanian body idioms" by Gaba (2018) presents data on the absolute correspondence, close correspondence, partial correspondence, and non-correspondence of idioms translated from English to Albanian language.

However, before showing examples from his research some definitions related to idioms will be presented which perfectly clarify their meaning and criteria of them:

According to Fernando and Flavell (1981) an idiomatic construction should have the following five properties:

1. Its meaning is not the compositional sum of its constituents;

2. It is a unit that either has a homonymous literal counterpart or at least individual constituents that are literal, although the expression as a whole would not be interpreted literally;

3. It is transformationally deficient in one way or another;

4. It forms part of a set of expressions in a given language;

5. It is institutionalised (found on Gaba, 2018).

In his study Gaba presents 687 English and Albanian idioms by dividing them into different groups in using correspondence as criteria to examine idioms. In addition, all "compared idioms correspond on all three levels i.e. on the semantic, lexical, and formal level” (Gaba, 2013, pg. 185).

Absolute correspondence:

Examples below are taken from Gaba's article:

Behind somebody's back- Prapa shpines së dikujt (Albanian translation).

According to him this idiom has an absolute correspondence with the Albanian idiom, more or less it can be stated that it has a direct translation without having any change in structure, form, or in the usage.

Other idioms pertaining in group of absolute correspondence:

"All ears/eyes"- "Gjithë sy e vesh" -Albanian translation; "Armed to the teeth"- "Armatosur deri në dhëmbë" -Albanian translation; "At heart"- "Në zemër, në shpirt" - Albanian translation; "At sight"- "Me të parë" - Albanian translation.

All the aforementioned idioms have an absolute correspondence in not changing their form nor their structure. Generally, it can be stated that all the above mentioned idioms and their translation in Albanian language correspond in levels of semantic, levels of lexical, and in formal level.

Close correspondence:

In close correspondence according to Gaba (2018) idioms are subdivided based on their variation:

"use of a different preposition"- fall under somebody's eye- "bie në sy të" (Albanian translation) (pg. 185); "use of singular vs. plural form"-blow one's nose- "shfryj hundët" (Albanian translation) (pg. 185); "use of a preposition vs. lack of it"-pat somebody on the back- "I rrah krahët dikujt" (Albanian translation) (pg. 185); "change of word order"-skin and bones- "kockë e lekurë" (Albanian translation) (pg. 185).

On the first variation the syntactic structure is as follows: verb+preposition+noun or non+preposition+noun, but the preposition is different in Albanian language compared to English:

For example: Under-në-in

On the second variation which deals with singular or plural forms which includes morphological changes such as:

-nose (singular) is translated as "hundët (plural)" which in English is "noses". 
Thirdly, the use of preposition versus lack of it includes "the fact that whether or not the same idiom employed in both languages contains a preposition" (Gaba, 2018, pg. 186).

The translation of the idiom "pat somebody on the back" ends up lacking its preposition while being translated in Albanian language.

Fourthly, the last variation includes the change of word order which is quite normal and acceptable during translation, such as:

"Skin and bones" to "Kockë e lekurë" (Albanian translation)

Partial correspondence

In partial correspondence enter idioms which only correspond on the semantic level. According to Gaba (2018) "they are either lexically non-equivalent or show differences in the syntactic structure" (pg.186).

According to him partial correspondence can be reached in five ways such as:

- use of a different body lexeme

- use of a meronym vs. holonym

- use of a different verb

- use of a lexically different word

- $\quad$ use of a lexeme verse a compound

On the first way it includes a different body lexeme even though in two languages the idiom expresses the same thing such as:

“Escape somebody's lips -Më shpëton nga goja (mouth) (Albanian translation); Lips- Buzët (Albanian translation); (Albanian translation): Goja-mouth

Secondly are idioms" that belong to this subcategory which are not equivalent in terms of the semantic relation of the body lexemes" (Gaba, 2018, pg. 186).

For example:

Hand to hand fighting - Luftë trup me trup (Albanian translation)

Thirdly, we have a group of idioms which "used verbs with different denotation, although the overall meaning of the idioms is the same" (Gaba, 2018, pg. 187).

For example:

"Feast one's eyes on"- Kullot sytë (Albanian translation)

Fourthly, we have use of lexically different words which include idioms that have different lexical means:

"Risk one's neck"- Rrezikoj kokën (Albanian translation)

This classification includes idioms which change the whole lexical items. If the above idiom would have a direct translation, there would be a meaningless and not understandable translation for Albanian readers or English readers and would be no coherence. So in this case the most appropriate technique is to change the lexical item in the target language such as: neck- kokën.

Non-correspondence

Lastly, Gaba (2018) shows the group of idioms which cannot be translated in Albanian language or vice versa because they do not have any correspondent, but the only solution which can be used is to "express idioms in other languages by using means which are not of idiomatic nature" (pg. 187).

This category is divided by him, into three subcategories such as: Periphrasis, one-word expression and free combination of language elements.

Periphrasis or description is used "to explain the meaning of an idiom if there is no idiomatic counterpart" (Gaba, 2018, pg. 187).

English: "At first hand"- "Nga burime të drejtpërdrejta "(Albanian)

One-word expression

Secondly, enter the idioms which can be expressed in the target language with only by one word, for example:

English: "Down in the dumps/mouth"- "I trishtuar" -(Albanian)

Free combination of language elements

In free combination of language enter "a combination of words which would express the reality 
expressed by the English idiom in the closest possible way" (Gaba, 2018, pg.187).

For example:

English- "Bite the hand that feeds one"- "Tregohem mosmirnjohës" (Albanian).

In a published article titled "Strategies in translating idioms and fixed expressions from English to Albanian language" by Poshi and Lacka (2016) there can be found many examples that verify the first strategy presented by Baker, such as:

English language: "I went to the dentist and asked him to fill the molar, and remove the wisdom tooth at the same time. Might as well kill two birds with one stone" (pg. 49).

Albanian language: "Shkova te dentisti dhe i kërkova të më mbushte dhëmballën dhe njëkohësisht të më hiqte dhëmbin e pjekurisë kështu, me një gur vrisja dy zogj” (pg.50).

As it can be noticed the idiom "kill two birds with one stone" has the same form and meaning in Albanian language and it can easily be translated.

According to Poshi and Lacka (2016) there are also other idioms which have similar meaning and form, while they are translated in Albanian language such as:

"Apple of discord" which has been borrowed from Greek mythology (Qesku, 200o, pg.43, found on Poshi \&Lacka, 2016, pg.50) and its translation in Albanian is "Mollë sherri" (Qesku, 200o, pg.43, found on Poshi\&Lacka, 2016, pg.50). Also idioms like: Be frightened to death (Siefring, 2004, pg.75) it can be found on similar form in Albanian as "Jam i trembur për vdekje" (Stefanllari, 1998, pg.127); Go downhill (Siefring; 2004, pg.45) in Albanian means "Shkon tatëpjetë" (Stefanllari; 1998,pg.127); Take your hat off to (Siefring; 2004, pg.85) = "Heq kapelen dikujt" (Stefanllari; 1998, pg.391); "You reap what you sow" (Siefring; 2004,pg.138) = "Ç’të mbjellësh do të korrësh” (Qesku; 200o,pg.878); "Reap the benefits (fruits) of (Siefring; 2004, pg. 324)= "Korr fitimet" (Stefanllari; 1998,pg.324); "Free rein" (Siefring; 2004, pg.240) = "Frerët e lira" (Qesku; 2000, pg.897).

\section{Methods}

The methodology used in this study focuses on the analysis of Albanian literary text translation "Ajkuna qan Omerin" into English by elaborating the strategies of translation, types of cultural losses, difficulties and solutions, which enable and disable the equivalence to take place in the target language in this case in English.

This research intends to tackle or identify strategies/ways, difficulties and solutions that Albanian students who study English language as a foreign language have used or mentioned during and after translation.

This study has been conducted based upon three research methods namely: Empirical, Quantitative and Qualitative research.

\subsection{The purpose of the study}

The purpose of this study is to show how Albanian students have achieved equivalence in translating Albanian literary text to English. Besides this, this study identifies translation strategies that students have used during the process, as well as the changes or modifications that they have done in order to realise the translation in the best way possible. This study also tries to find out difficulties or challenges that students have reported after doing the translation and the solutions used in order to come up with a general conclusion of finding an appropriate method to make future literary text translation in the most coherent and equivalent way.

\subsection{Research Objectives}

The objectives of this study are:

- To identify translation strategies that students have used during the process of translation and the extent to which such used methods have been appropriate to Albanian literary text 
translation. In addition, this study tends to find changes or adjustments of verb tenses and moods that students have done during the process of translation since Albanian verb moods and tenses do not have the same grammatical features in English.

- To identify types of cultural losses that have occurred during the Albanian literary text translation to English language, including here the translation of Albanian idioms and fixed expressions, Albanian metaphor, and Albanian cultural words.

- To find out difficulties or challenges that students have reported after they translated literary texts to English as well as their solutions that they recommended based on their personal experience with Albanian literary text translation.

\subsection{Research Hypotheses}

This research is focused on these hypotheses:

H1. The strategies of translating Albanian literary text into English language mostly used by Albanian students are borrowing, omission, and adaptation.

$\mathrm{H} 2$. Mostly, the types of cultural losses that can be found in the Albanian students' translation are modified and complete cultural losses.

$\mathrm{H}_{3}$. Students have many difficulties in achieving equivalence on Albanian literary translation into English as a consequence of many differences in grammar (the non-equivalence between Albanian and English verb moods), and in translation of Albanian cultural words, idioms or fixed expressions. The solutions to eliminating such difficulties or challenges are: having a general knowledge of the source language, mastering the grammar system of both source and target language (recognition of similarities and differences) using dictionaries such as: Albanian-Albanian dictionary, Albanian-English dictionary and the use of different translation's strategies in order to deal with such difficulties or challenges.

\subsection{Sample of research}

The research was conducted with Albanian students who study English language and literature, after they had taken the literary text translation course. Participants were Albanian students, from university of Gjakova "Fehmi Agani", faculty of Philology, department of English language and Literature and from University of Prizren "Ukshin Hoti”, faculty of Philology, department of English language and Literature. Students who participated in this research were in the third year of their studies and their selection was based on their fluency in English, and those who had at least 8.o GPA. As was planned from the very beginning, 35 students participated from University of Gjakova and 35 from University of Prizren, who had to translate the text "Ajkuna qan Omerin". Those who managed to translated the aforementioned text participated in the second phase, which was the questionnaire, in which they had to answer two open-ended questions.

\section{Collecting Data}

The data for this study have been collected from Albanian students' translations in University of Gjakova "Fehmi Agani" and University of Prizren "Ukshin Hoti". Students had in hard copy Albanian literary text, and they translated in hand writing. After, they had to answer two open-ended questions from the questionnaire, related to challenges or difficulties they experienced during Albanian literary texts translation. From 70 students who participated in the translation of the text "Ajkuna qan Omerin" only 57 participants translated the text, which means 13 students gave up translating the aforementioned text.

627 sentences altogether were analysed for "Ajkuna qan Omerin”, in order to find out the types of translation strategies that students had used, and also the types of cultural loss, which had occurred during translation. 
The questionnaire for "Ajkuna qan Omerin" has been completed by those who only have done the translation and the number of questionnaires was 57 .

\subsection{Collecting and Presenting data}

The purpose of this study was to find out the problems of equivalence while translating Albanian literary text into English, ways of achieving equivalence, difficulties/challenges that students faced during such translations, and lastly the solutions that can overcome such difficulties or challenges. Below is presented the table 5 . which shows the number of universities and students' participation:

Table 1: List of numbers of students for participation for the text and the number of students who translated the text.

\begin{tabular}{|l|c|c|c|}
\hline Text translated & No. of participants in translation & No. of participants who translated the text & $\%$ \\
\hline “Ajkuna qan Omerin” & 70 & 57 & $81.42 \%$ \\
\hline
\end{tabular}

As it can be seen, from the above table 70 students participated in the study, 35 from each university. text "Ajkuna qan Omerin" has been translated by 57 students out of 70 , or $81 \%$ of them.

Table 2: List of universities, faculties and departments, numbers of students for participating in the questionnaire.

\begin{tabular}{l}
$\begin{array}{l}\text { University of Gjakova "Fehmi Agani”, Location: Gjakovë, Faculty of Philology, Department of English language } \\
\text { and literature. } \\
\text { University of Prizren “Ukshin Hoti”, Location: Prizren, Faculty of Philology, Department of English language } \\
\text { and literature. }\end{array}$ \\
\hline Students participating in questionnaire of the Text: “Ajkuna qan Omerin” \\
\hline $57 / 81.42 \%$ \\
\hline
\end{tabular}

The questionnaire, as the second part of this study, was completed after the translation of the Albanian literary text. The intended number of students filling in the questionnaire was 35 from each university and only for those who have translated the aforementioned text.

57 participants or $81.42 \%$ of them, who translated "Ajkuna qan Omerin" filled in the questionnaire.

\subsection{Data analysis on translation strategies used in Albanian literary text "Ajkuna qan Omerin"}

Table 3: Translation strategies used during the translation of Albanian literary text "Ajkuna qan Omerin"

\begin{tabular}{|c|c|c|c|}
\hline Translation Strategies & Number of translated versions & Number of Strategy used & $\%$ \\
\hline Adaptation & 57 & 56 & $98.2 \%$ \\
\hline Direct Translation & 57 & 53 & $92.98 \%$ \\
\hline Omission & 57 & 18 & $31.57 \%$ \\
\hline
\end{tabular}

Only 57 students out of 70 translated the text "Ajkuna qan Omerin”. "Ajkuna qan Omeri” has 11 sentences, which means there were analyzed 627 sentences individually.

From the analysis of 627 sentences, of 57 versions, there were identified three types of translation strategies, such as: adaptation, direct translation and omission.

The majority of students have used adaptation strategy, which according to table nout of 57 
versions of translation adaptation is used in $98.2 \%$ of the translated versions, whereas direct translation strategy appears in $92.98 \%$. Omission is used in few cases, in 18 versions or $31.57 \%$.

Each of the strategies used in translation of "Ajkuna qan Omerin" helped students to realise the translation in the best way possible. Based on the 627 sentences' analysis it can be stated that students have changed the word order, word class, have added interjections and have shifted the finite verb form into non-finite, as a result of lack of optative verb mood in English. Except these changes they have also added new words and at the same time have omitted others because of their non-equivalence to English.

In none of the 57 analysed versions there was identified the use of only one translation strategy, almost in all of them there were used mixed translation strategies.

\subsection{Data analysis of cultural losses in translation of Albanian literary text "Ajkuna qan Omerin"}

Table 4: The data analysis of types of cultural losses identified in the translation of Albanian literary text "Ajkuna qan Omerin"

\begin{tabular}{|l|c|c|c|c|c|}
\hline $\begin{array}{l}\text { No of translated versions of } \\
\text { text "Ajkuna qan Omerin" }\end{array}$ & \multirow{2}{*}{ Number of Cultural losses } & \multicolumn{2}{|c|}{ Modified Cultural Loss } & \multicolumn{2}{|c|}{ Complete Cultural Loss } \\
\cline { 3 - 6 } & & No & $\%$ & No & $\%$ \\
\hline 57 & 114 & 57 & $100 \%$ & 57 & $100 \%$ \\
\hline
\end{tabular}

Regarding the above table, we can see modified and complete cultural loss that have occurred in the translation.

In 57 versions, the occurrence of modified and complete cultural loss is the same in percentage. So, in all versions, both types of cultural losses have been identified.

\subsection{Data analysis of types of difficulties on questionnaire of "Ajkuna qan Omerin" text translation}

Table 5: Data analysis of types of difficulties on questionnaire of "Mëngjesi" and "Ajkuna qan Omerin" text translation

\begin{tabular}{|l|c|c|c|}
\hline Text 1\&2 Challenges and Difficulties & $\begin{array}{c}\text { Number of } \\
\text { questionnaires }\end{array}$ & $\begin{array}{c}\text { Number of mentioned } \\
\text { difficulty }\end{array}$ & $\%$ \\
\hline Types of Difficulties & 57 & 57 & $100 \%$ \\
\hline Difficulties in translating Albanian cultural words & 57 & 50 & $87.71 \%$ \\
\hline Differences in grammar among Albanian and English & 57 & 17 & $\mathbf{2 9 . 8 2} \%$ \\
\hline Difficulties in translating idioms or fixed expression & & & 17 \\
\hline
\end{tabular}

From the qualitative data collected from the questionnaires, concerning difficulties or challenges of translating "Ajkuna qan Omerin", there were identified three major types of difficulties, such as: Difficulties in translating Albanian cultural words, differences in grammar among Albanian and English and difficulties in translating idioms or fixed expression.

From 57 questionnaires, related to the first question about difficulties or challenges of translating "Ajkuna qan Omerin", 100\% of students responded that they found difficulties in translating Albanian cultural words. The majority of responses were that such difficulties came up because of the lack of English grief words which prevented the equivalent translation to take place. Furthermore, they stated that transmitting emotions from the ST to TL was one of the most difficult targets to achieve in the translation of the "Ajkuna qan Omerin".

They also found challenges or difficulties in understanding the meaning of Albanian cultural words. At this point, they declared that they lack cultural knowledge because of insufficient reading of Albanian literary works, which lead them to misunderstand the meaning of Albanian words.

Whereas, $87.71 \%$ of the students stated that "differences in grammar among Albanian and 
English" caused problems in making a coherent and equivalent translation to TL. Their main difficulty has been the non-equivalence of verb moods among Albanian and English, specifically the subjunctive and optative verb mood, which lack in English.

Lastly, $29.82 \%$ of responses from 57 questionnaire considered a difficulty or challenge in the translation of Albanian idioms or fixed expression to English. They found it very hard to find an appropriate adjustment of Albanian idioms to English since the majority of them (that were found on both texts) did not correspond to any, in English.

Below are some of the students' responses related to difficulties or challenges that they had or faced during translation of "Ajkuna qan Omerin"

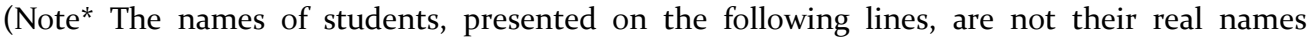
because of the ethics of privacy).

As for difficulties in translating Albanian cultural words, student Ana stated:

"Literary translation from Albanian to English is one of the hardest. I had difficulties in translating cursing words and adjusting verbs that were in optative verb mood because they are not equivalent in English at all"

Also, Nora student wrote:

"Translating from Albanian to English is more difficult than from English to Albanian because Albanian language has much more verb moods than English. And the great challenge was the translation of Albanian cultural words"

Whereas, student Tina said:

"The challenge was translating Albanian expressions like "Haj medet" "paça lanë", Amanet, etc."

Student Besian wrote:

"Albanian literary translations are very hard to be translated. Most of the time I had difficulties in finding the right words in English, to express emotions that were in Albanian text. Also I had difficulties in adjusting expressions or idioms that were in "Mëngjesi", and in this cases I had to reduce the whole idiom and expression"

For difficulties in translating idioms or fixed expression, student Era stated:

"The challenge was in translating idioms or expressions to English, was quite hard in finding one with the same meaning in English".

\subsection{Data analysis of types of solutions on questionnaire of "Ajkuna qan Omerin" text translation}

Table 6: Data analysis of types of solutions on questionnaire of "Ajkuna qan Omerin" text translation

\begin{tabular}{|l|c|c|c|}
\hline Text 1\&2Solutions & $\begin{array}{c}\text { Number of } \\
\text { Tyestionnaires }\end{array}$ & $\begin{array}{c}\text { Number of solution } \\
\text { mentioned }\end{array}$ & $\%$ \\
\hline Reading more in Albanian literature & 57 & 51 & 43 \\
\hline Usage of different translation strategies & 57 & $\mathbf{4 3}$ & $75.43 \%$ \\
\hline Enrichment of Albanian-English dictionary & 57 & $\mathbf{2 7}$ & $47.36 \%$ \\
\hline Usage of Albanian-Albanian dictionary & 57 & $\mathbf{1 2}$ & $21.05 \%$ \\
\hline
\end{tabular}

In respect of the second question of the questionnaire about the solutions in order to meet the difficulties or challenges, students' responses have been categorised in five groups such as: reading more Albanian literature, using different translation strategies, enriching Albanian-English dictionary 
and using Albanian- Albanian dictionary.

According to the above table, $89.47 \%$ have claimed that as a solution to eliminate problems while translating Albanian literary texts to English can be if a translator is a deep reader of the source language, especially of Albanian literature. Additionally, they stated that if they read more Albanian literature they would easily translate such texts to English because of the prior knowledge of Albanian culture shown in literature.

On the other hand, the second solution mentioned by $75.43 \%$ of the students is the use of different translation strategies which will enable a coherent and equivalent translation to TL. The most mentioned translation strategy for such Albanian literary texts translation was omission, and secondly borrowing.

The third solution refers to the "Enrichment of Albanian-English dictionary", which $47.36 \%$ of students have considered as a great help in order to translate in the best way possible. Students have highlighted if we had Albanian-English dictionaries, which would be suitable for literary word translation specifically containing translation of Albanian cultural words to English, we would minimise the challenges or difficulties.

$21.05 \%$ of the students have recommended that another useful solution can be the use of Albanian-Albanian dictionaries which will help translators firstly to understand the meaning of a source words and then to realise their translation to TL. This recommendation is coherently linked to the previous table15 (related to difficulties or challenges during translation) which show that students lacked an understanding of the meaning of Albanian cultural words, idioms and fixed expressions because they declared that they do not read frequently in Albanian literature. This is why they have had difficulties or challenges in understanding the culture of Albanian language, in terms of utterances, expressions, idioms and etc.

Below are presented some of the students' solutions regarding the difficulties and challenges in translating "Ajkuna qan Omerin":

As for the solution "Reading more in Albanian literature", student Gresa stated:

"If we read more and have background knowledge of different fields and terms it would be easier to translate. Sometimes we have to omit some words and change other words in order to convey the same meaning of source language"

Also, student Andrea wrote:

"Reading more in Albanian literature is the first step that translators should do and having knowledge on literary translation. Related to translation of idioms or fixed expressions translators might omit them or find another idiom or fixed expression which is close to the source language"

Whereas, for the second solution "Usage of different translation strategies", student Tina said:

"In order to find solutions related to difficulties of translating Albanian cultural words, expressions, or any sentence which has any verb mood that isn't found in English we should use different ways. For example, to omit the word or expression which cannot be found in English or in some cases to use the same one as it is in Albanian language"

Same solution has been mentioned by student Jeta:

"If we use different translation strategies, we would translate easier in such literary texts. Omission and borrowing, for my opinion, can really help in cases if there isn't any equivalent word in English or if there isn't any choice left when it comes to translation of Albanian idiom or expression"

About "Enrichment of Albanian-English vocabulary" as a solution, student Nora said:

"There can be many solutions which can make easier the process of translation such as: the enrichment 
of Albanian- English dictionary because many words that were find in both texts were not found in any Albanian-English dictionary, it will be helpful if they work in enriching such dictionaries with translation of Albanian cultural words to English"

As well student Endrit shared the same answer:

"Frankly speaking I have never dealt so deeply with literary translation and now that I had the case I noticed that there is huge lack on finding Albanian cultural words translation to English in current Albanian-English dictionaries. I think that we should have dictionaries which have Albanian cultural words translation to English or any other helpful material.

As for "Usage of Albanian-Albanian dictionary", student Mali answered:

"As a result of not reading in Albanian literature I found the texts difficult and in such cases while dealing with cultural words or expression a great solution might be the usage of Albanian-Albanian dictionary. Secondly might be the usage of omission, shifting from literary meaning to non-literary one (while translating idioms or fixed expressions).

To same solution, also student Ardi stated:

"There can be many solutions to eliminate such difficulties but for my opinion the very first should be to have an Albanian-Albanian dictionary beside you whenever dealing with such literary text translations. If still there are difficulties, we should omit or add words in order to do the translation in the best way possible. Generally, for my opinion I think that no matter what changes a translator might do the most important thing is to transmit the same message as it is in SL."

\section{Discussion}

The text "Ajkuna qan Omerin" expresses strong emotions shown by optative Albanian verb moods, which lacks in English language. The text seemed difficult to be translated in the most equivalent way in English because it contained Albanian idioms or fixed expression that can hardly or never have an equivalent or a coherent translation to TL.

“Ajkuna qan Omerin” known as Ajkuna's lament is a lyrical part of Kreshniks' songs, one of the best and the saddest part in all the book.

The mourning of Ajkuna comes after she is informed about her son's death. She expresses all her feelings by lamenting Omer, who is buried by his father and uncle.

The translation of this part from Kreshnik's songs requires an art, a talent and a great commitment. "Ajkuna qan Omerin" generally consists of different Albanian cursing words, followed by optative verb mood which gives strong emotions to lines. The verb in optative mood is used "to convey good and bad wishes" (Danile \& Dobrushina \& Ganenkov, 2019) of the speaker. The optative mood is quite interesting and rare, in addition, it can hardly be translated in other languages which do not have it. Thus, such feelings or enthusiasm of expressions are almost impossible to be transmitted in English language with same emotions or enthusiasm as they are in Albanian language.

The analysis of 627 sentences shows that $98.2 \%$ of students have used adaptation as a translation strategy, $92.98 \%$ have used direct translation and omission is employed by $31.57 \%$ of the students. Basically, they tried hard which they pointed out in their answers to the open ended questions.

Based on the analysis of students' translation of "Ajkuna qan Omerin" it can be stated that students have changed the word class, added, omitted and changed from main verbs (of SL) to nonfinite verb form, as a result of optative verb mood in SL. In addition, they have used different interjections in order to transmit the same emotions as presented in SL and have implemented the coherence by incorporating the subject to the TL.

Below, are shown some of the versions of students' translation which show the changes that 
were mentioned above:

"Haj medet, tha, mori bjeshkë, se tetë Omera t'mirë si i paç e tetë Omera ndër ju t'dekun i laç. Ju u thaçin Bjeshkët e thata, Dushk as bar ndër ju kurr mos dalt, As uj ndër ju kurr mos u piftë!" (Kangë Kreshnikësh dhe Legenda).

1. "Oh God, you mountains, she said, I had eight great boys in Omer and I left all of them dead among you"

2. "Oh my mountains, she said, the eight gracious Omers I had and eight Omers to you I have left dead"

3. "Woe to you, oh mountains, eight good Omers I had and eight of them I have left to you dead"

4. "Oh woe, you mountains, I had eight gentle Omers and eight Omers I have left to you"

5. "Alas, oh you, mountain meadows, for eight Omers' did I have and all eight of them on you their last breath took"

Looking into versions of students' translation it can be stated that almost all students added interjections such as: "Oh God", "Oh", "Woe", "Alas", as translated versions for the Albanian expression "Haj medet". This Albanian expression is used to express a surprise for worries or problems in real life.

Generally, all the versions used the addition of interjections "Oh God" to refer the Albanian expression which is not equivalent in English language and there is no way to use direct translation strategy.

Furthermore, as it can be noticed that students have added the subject "She" which isn't in SL because the beginning of "Ajkuna qan Omerin" is in direct speech and some of the students while translating have transformed into reported speech by adding the subject in some lines. In addition, in Albanian language there are sentences which do not consist of subject and reference because both subject and reference are in speaker's mind. On the other hand, in English language it is necessary to understand the subject and the reference especially while translating from Albanian to English language. Almost in all students' versions of the translation of the above line have been added the subject "She", "I" and the reference "you" which lead to state that the use of cohesive devices enables this line to be equivalent and coherent to English language (TL).

The following versions of the next translated lines refer to changes to the Albanian optative verb mood into different structures:

"Ja u thaçin Bjeshkët e thata, Dushk as bar ndër ju kurr mos daltë, as uj ndër ju kurr mos u piftë"

1. "May your mountains become dry, may oak or any grass never grow, nor water among you may never be drunk"

2. "May they call you parched pastures, no leaves nor grass grow on you, nor no one ever drink your water"

3. "I curse you. Let the people name you dry mountains, let there no oak or grass grow on you, or any track of drinking water"

4. "May dryness overwhelm you, may no oak or grass grow on you, nor water amidst you ever be drunk"

The lack of optative verb mood in English language has led students to find different ways of making an equivalent translation to TL.

As it can be seen, students have mostly added the modal verb "may" to express a curse and wish at the same time, in order to replace the optative verb mood of "mos daltë", "u piftë", "thaçin". In addition, the majority of versions of these translated sentences consist of the modal verb "may". The exception is the third version, in which it can be noticed the addition of full sentence "I curse you" for the purpose to transmit the strong emotions that optative verb mood gives to these lines.

Even though it cannot be stated that the only way to make equivalence of optative verb mood in English is the addition of modal verb "may", because there might be other different verb forms which enable the equivalence or coherence to take place in TL.

The next versions of the students' translation show the problem of translating the Albanian word "Amanet" and the use of the conceptual metaphor: 
"Amanet, mor llavë, jau paça lanë: Kur t'u qesin rruga ksajt me ra, Mos me britë, as dajre mos me ba, Pse kam Omerin ktu djalë të ri, M’përmallohet e malli e merr për shpi”

1. "I leave my earnest will to you oh wolf pack: If you happen to step past here, do not howl, nor make a fuss, for here lies my Omer, a young lad"

2. "I have one wish for you wolf packs: When your road takes you here do not howl or make disturbance because here lies my son Omer"

3. "I plead to you people: When you walk this way, do not cry out, do not play any music, here rests a young boy Omer, he will long and miss home"

4. "I leave a will to you crowds: when you come this road, do not scream, do not play the tambours, because I have the young Omer here, and he will miss home"

5. "Last will you crowds of people as I leave it to you: when the road brings you around do not cross, do not scream, do not play neither tambours since I have here Omer, a young boy, he will long and will miss his home"

Based on the analysis of this part of "Ajkuna qan Omerin" students had problems in translating the word "Amanet", which forced them to transform it into different sentences in order to make an equivalent translation and to transmit the same message in SL.

"Amanet" in Albanian language means:

1. “M. bised. Një gjë që ia lëmë dikujt për ta ruajtur e për t’u kujdesur për të; porosi që ia japim dikujt për të na bërë patjeter një punë. Lë amanet. E kam amanet. Jap një amanet."

2. "Dëshira ose porositë që lë njeriu me fjalët e fundit para vdekjes. Amaneti i babait. Amaneti i dëshmorëve" (Fjalor shqip, n.d).

According to Fjalor shqip (n.d) the word "Amanet" means:

1. When we leave a thing to someone and to care for, a message that we give to someone to do a job for us"

2. The wish or desire/messages that someone leave in the final word before death.

Referring to students' translation of the word "Amanet" we have these versions:

1. "I leave you my earnest will"

2. "I have one wish for you"

3. "I plead to you"

4. "I leave a will"

5. "Last will"

Except in above versions, the rest of them have the same version as is in the second one, referring to the translation of the word "Amanet". Generally, all the versions are coherent and transmit the same intention of SL to TL. In addition, it can be stated that all versions above have modified cultural loss's occurrence, whereas the last one consist of complete cultural loss, since it is considered as poor translation toward the transmission of the closest meaning of the word "Amanet".

The identification of the usage of conceptual metaphor has been in the sentences:

"Amanet, mor llavë."

Students' version

"I leave my earnest will to you oh wolf pack...:

"I have one wish for you wolf pack..."

In Albanian language the word "llavë" refers to groups of people or crowds of people but in some students' translation regarding this word they have used the word "wolf pack, which shows the use of the conceptual metaphor. Even though students might have unconsciously used the conceptual metaphor they have realised a good replacement of "people" with "wolf pack", because if we analyse the context of the whole story, and the pain of the mother and her lament, the use of the conceptual metaphor best fits in this case. 
Conceptual metaphor is "understanding one domain of experience (that is typically abstract) in terms of another (that is typically concrete)" (Kövecses, 2017, pg.1). So basically, the use of the conceptual metaphor is when we want to express our feelings, strong emotions, people's qualities, objects and situation by saying them indirectly in terms of another. Çeliku (2013) in his research "Realisation of text coherence in English and Albanian languages through conceptual metaphors" makes an analysis of coherence's implementation during the translation of some specific expressions from Albanian to English language and their non-coherence during the translation.

In addition, Çeliku (2013) states that:

The metaphor has been a stylistic figure since Aristotle's time whose job is to provide poetic language and philosophical or political speech to make a lively storyline. But with the cognitive revolution of the 1970 's, with the emergence of conceptual semantics, there was a shift in the interest of traditional treatment of metaphor for a modern treatment focusing on the concept of conceptual metaphor (pg.1)

Conceptual metaphors are grounded in everyday experience. Lacoff and Johnson (2003) in their book "Metaphors we live by", state:

The concepts that govern our thought are not just matters of the intellect. They also govern our everyday functioning, down to the most mundane details. Our concepts structure what we perceive, how we get around in the world, and how we relate to other people. Our conceptual system thus plays a central role in defining our everyday realities. If we are right in suggesting that our conceptual system is largely metaphorical, then the way we think, what we experience, and what we do every day is very much a matter of metaphor. (pg.4)

According to Çeliku if "languages develop cognitive metaphors then the different linguistic communities develop cognitive structures" (2013, pg.1). These cognitive metaphors are found in his research for Albanian and English comparisons presented during the translation such as:

"Ai është ujk Mali!" (He is a wolf) (Çeliku, 2013, pg. 2); "Ai është qen i punës!" (He is a dog of the work) (Çeliku, 2013, pg. 2); “Ai është derr!” (He is a swine) (Çeliku, 2013, pg.2)

Finding animal metaphors in languages informs the reader about the characteristics of a person. Features of a person compared to animals may express positive or negative characteristics always by being based upon the context or on the situations. The above sentences translated into English language may seem awkward or misunderstood by native English people, who may end up reading a non-coherence translation. According to Çeliku (2013) a metamorphism in the Albanian language has a huge difference in use compared to English language.

For example:

"Ai është qen i punës"- (He is a dog of the work) it expresses good features of a person, by describing him as a hard worker, who works a lot and does a great job. Also, in a case of "He is a swine" means he has good manners.

Also, other comparisons which describe good qualities of people are shown below:

"Ajo është një dreq vajzë!” (She is a devilish girl!); “Ai është një kopil!" (He is an illegitimate son) (He is a bastard). According to Çeliku (2013) the noun phrase such as a devilish girl, an illegitimate son and a bitch, express good qualities of a person. In Albanian language such comparisons describe how smart and skillful a person is.

Also, folk songs and poetry contain many Albanian metaphors such as:

“Moj nëperka pika-pika” (O you colorful viper!); “Të dua moj qëne!” (I love you my bitch!) (Female dog); “Të dua mor zagar" (I love you my stud!) (Male dog)

The expression of love is compared by such comparisons with animals that give more artistic value and emotions.

Çeliku (2013) shows other examples of metaphor, which he considers as "the love or the closeness to a particular person in the Albanian language is also expressed by the metaphorisim of this type”: "Sa i keq që je!” (How bad you are!) (Çeliku, 2013, pg. 2) "Sa budallaqe që je!” (How stupid you are!) (Çeliku, 2013, pg. 2) "Sa e mire që është shtriga!" (How beautiful is the witch) (Çeliku, 2013, pg. 2) "Sa i zgjuar është dreqi!" (How wise is the devil) (Çeliku, 2013, pg.2) 
Generally, conceptual metaphors have a crucial function in implementing the textual coherence, and yet the translator has to take care how he/she picks the comparisons (in these cases, animals) in order not to cause confusion or misunderstandings among different cultures or different metaphoric ways that languages share. In this case, students used "wolf pack" to refer to people who will pass that road where Omer is buried and at the same time capture the pain, and the hate of Ajkuna toward nature and all human beings, by naming them as wolves. In this case, the use of conceptual metaphor makes the translation more artistic and expresses hate, pain and at the same time by making a coherent and equivalent translation as well.

Generally, the majority of students' versions of "Ajkuna qan Omerin" have been equivalent to English, with the exception of some Albanian words which students ignored totally or left an empty space and continued to translate the rest of the lines.

These Albanian words which some students ignored are:

1. M'merohet

2. M'përmallohet

3. "Gjogave"

4. "Mori nuse"

The reason for the total ignorance of the above Albanian words might be because of the lack of understanding their meaning in Albanian language. Not accidently it can be concluded that way because they admitted in the questionnaire that they faced challenges or problems in some Albanian words translation because of not understanding words' meaning. $34 \%$ of students declared that they needed to develop their knowledge of Albanian language by reading more Albanian literature.

Thirteen students (or $18.57 \%$ ) gave up translating "Ajkuna qan Omerin" because they found it very difficult and impossible to translate to English. Even though this difference in numbers is quite normal because the presence of the optative verb mood, Albanian cultural expressions and Albanian interjections found in "Ajkuna qan Omerin" made the translation much more difficult.

Such issues have also been shown based upon the data analysis of the questionnaire that students have filled in after translating the two aforementioned Albanian texts.

Students, who translated both texts, have stated that for them, there have been many challenges and difficulties. The most repeated challenges were the translation of old Albanian words and the non-equivalence of verb moods amongst Albanian and English.

Student B. said: "The difficulty I had during translations were mainly with the old Albanian words, which I as a native speaker of Albanian language could not understand the meaning and then comes the problem of translating them. The other problem was with the differences in verb moods between Albanian and English. The lack of subjunctive and optative mood in English caused me many difficulties in translation. Lastly, as I mentioned at the very beginning the hardest one I consider the translation of expressions like "Haj medet".

Another response related to the difficulties translation was:

"Difficulties that I had during translation of both texts were the translation of old Albanian words and the translation of verb that were in "mënyra lidhore" and "mënyra dëshirore". Also the translation of idioms or fixed expression caused difficulties in finding an appropriate translation".

The problem of translating old Albanian words refers to cases which were highlighted above, such words caused a number of changes as well as ignorance to TL. Whereas the non-equivalence of the verb mood refers mostly to the text "Ajkuna qan Omerin" because of the optative verb mood which lacks in the English language.

Other challenges or difficulties that students have mostly mentioned were the non-equivalence of Albanian and English idioms and the translation of Albanian mourning words to English language.

The non-equivalence of idioms amongst Albanian and English was referenced in the discussion of the "Mëngjesi" translation, which led students to make non-coherent translation. The non- 
equivalence of Albanian idiom and fixed expression effected many changes to word and sentence levels by changing the word class, omission of sentence elements as well as addition of different cohesive devices.

Below, are shown two responses from students, regarding the difficulties or challenges that they had or faced during translation of "Mëngjesi" and "Ajkuna qan Omerin":

Student's response: "Albanian literary translation can be very hard to translate. Most of the time I had difficulties in finding the right words in English, to express the emotions that were found in the texts. For example, when translating a sentence such as "Të shkoftë puna mbarë" it was very hard to find an equivalent translation for it, since English doesn't have any verb mood that corresponds to it. Also many times I had to reduce some words and then add some other words in order to make it sound better in English".

Student's response: "For my opinion, the translation from Albanian to English is pretty hard to be realized. Challenges fall under the translation of idiom or fixed expression and the on the translation of verbs which were in "mënyra dëshirore" that lacks in English".

Other challenges or difficulties less mentioned included difficulties in transmitting the same emotions from SL to TL, Albanian translation utterance to English language, lack of knowledge related to Albanian words and the lack of English mourning words or expressions. For example, one of the students responded this way, regarding to lack of knowledge of Albanian words:

Student's response: "To be specific the most difficult part in translating Albanian literary texts was my lack of knowledge concerning Albanian words! I have struggled with this issue since the start because most communication I face is in English and therefore reading Albanian literature was never my priority, until now".

To all these challenges, that students have written on their first question in the questionnaire, were given solutions based on their own experience related to both Albanian literary texts translation.

The difficulties they experienced were related to three main factors. First a sound knowledge of the mother tongue, mastery of English by reading extensively and use of translation strategies, namely the use of omission as translation strategy, as can be seen in two responses of students, presented below:

Student's response: "The first solution that is possible is reading in Albanian more. However, I have to admit that languages come quite naturally to me so facing such problems was a rare issue" Second solution, might be the usage omission in cases when there is no choice left, because some of the Albanian words found in both texts don't have any way to be translated in English"

Student's response: "Maybe English language should add more words in their dictionaries (vocabulary) since if we compare the number of mourning words there is a great lack of English mourning words compared with Albanian language"

Student's response: "A good solution can be to omit the words that cannot have the right translation to English to use shifting from literary meaning to non-literary one"

The fact that students declared by themselves that they did not understand the meaning of Albanian words says a lot about the lack of language knowledge because of the lack of reading in Albanian, as was mentioned in one of the student's response:

"There can be many solutions for example as a good Albanian translator you must know all the vocabulary of source text or with one word he or she must have great knowledge on Albanian language culture in order to translate in the best way possible. You also must deal every day with Albanian literature in order to be a perfect translator" 
Logically, people start to forget their own language when they stop reading or analysing it daily or monthly, maybe the reason might be that they have been too focused on their English studies and that's why they considered this as a solution. As Newmark (1995) highlighted that "I shall assume that you, the reader, are learning to translate into your language of habitual use, since that is the only way you can translate naturally, accurately and with maximum effectiveness. In fact, however, most translators do translate out of their own language.

Whereas Baker in her book "In Other Words" writes...one of the most difficult tasks that a translator is constantly faced with is that, notwithstanding the 'fuzziness' inherent in language, he or she must attempt to perceive the meanings of words and utterances as precisely as possible in order to render them into another language." (Baker, 1992/2018, pg16). A translator must be very proficient in both the source and target languages.

On the other hand, omission as a translation strategy has been suggested to be used during such Albanian translations since it will reduce difficulties or challenges while dealing with Albanian cultural word translations. Even though the overuse of omission cannot be allowed to happen, otherwise the translation will end up as non-coherent and totally non-equivalent to a TL.

Another solution or suggestion that students have mostly mentioned were the enrichment of Albanian-English vocabulary related to Albanian cultural word translation, which will help most translators of Albanian literary books to English language.

The other solution, which is considered interesting is the usage of Albanian-Albanian dictionaries while having such translations to English language, as stated below by students:

Student's response: "The usage of Albanian-Albanian dictionary is a great solution to face challenges while translating such Albanian literary texts since I had many difficulties in understanding such Albanian words or expressions"

Student's response: "Having a wider knowledge of Albanian words especially the works of great Albanian writers such as Fan Noli, Ndre Mjeda, Ismail Kadare, etc. Having an Albanian-Albanian dictionary is also helpful when we deal with works as such".

Questionnaires provided us data from the students' reflections of their own experience in Albanian literary texts translation during "Mëngjesi" and "Ajkuna qan Omerin". They identified their difficulties and the reasons as well as suggested solutions of equivalence problems related to Albanian literary text translation.

\section{Conclusions and Recommendations}

Based on what have been discussed in relation to Equivalence problems during the translation of "Ajkuna qan Omerin" from Albanian into English language it can be generally stated that Albanian literary translations require care and attention together with hard work in dealing with equivalence problems during such translation.

Regarding the hypothesis of scientific work which were set at the very beginning, it can be stated that:

The first hypothesis, related to strategies of translation that students have mostly used in three Albanian literary texts, has been supported by analysis of students' translations which show that they mostly have used: direct translation, adaptation, omission and borrowing as translation strategies.

Whereas, the second hypothesis has been supported based on the analysis of students' translations, which prove that only two types of cultural losses have occurred in their translation such as: modified and complete cultural loss.

According to the data from the questionnaire, the third hypothesis, related to difficulties/challenges and solutions that students have suggested, has been supported by the two most stated difficulties or challenges related to translation of three Albanian literary texts. The highest percentage as a difficulty for three texts is "difficulties in translating Albanian cultural words" 
and less mentioned but not least are "differences in grammar among Albanian and English" which refers mostly to changes in tenses and verb moods amongst the two languages.

Considering the solutions offered by students, most have mentioned the usage of translation strategies such as omission, adaptation and borrowing, having a prior knowledge in Albanian culture, referring to the understanding of Albanian cultural words, and the use of Albanian-Albanian dictionaries while dealing with such Albanian literary text translations.

The theory of equivalence has the world of translation based on the differences that two different languages have, especially when it comes to the translation process. Referring to the theoretical approach and different recent studies done so far, Albanian and English language shave more differences than similarities in grammar, as well as in culture. Such differences cause challenges and problems when it comes to translation, especially to literary text translations. When it comes to equivalence among these two languages a lot $\mathrm{o}=\mathrm{f}$ changes should be completed in order to transmit the same message or meaning from target to source language.

As it can be seen from the title, the whole analysis of equivalence problems has been from Albanian to English, including the analysis of literary text translated by Albanian students who study English language and literature, as part of this research work.

The three Albanian literary texts translated by the students of University of Gjakova and University of Prizren show that equivalence can hardly be achieved in such translations. The same applies to the implementation of textual coherence. Taking into account the data from the comparative study of the translated versions of literary texts, as well as discussions, it can be stated that equivalence has been implemented via translations strategies, followed by addition of words, omission of words, shifts from literary meaning to non-literary meaning, implementation of conceptual metaphors. The translation strategies that have been identified during the analysis of students' translations were direct, adaptation, borrowing and omission. Such strategies enabled students to make a coherent and an equivalent translation, with the exception of some cases where they lacked on coherence implementation because of the overuse of direct translation strategies.

Generally, it can be concluded that in cases where paragraphs contained Albanian cultural words, expressions as well as idioms, the most functional translation strategy, which enabled the equivalence as well as coherence in SL, has been the adaptation translation strategy. The use of adaptation or free translation helped students to adjust such issues to SL in the best way possible, since students who used such translation strategies have made different changes to word classes and shifts from idioms or expressions to simple sentences.

To sum up, paragraphs which have been translated using adaptation, contained mostly modified cultural losses, because of the equivalence or mid equivalence of expressions or idioms among Albanian and English.

On the other hand, the direct translation strategy has functioned perfectly but only in cases where the sentence has had equivalent words in the English language. Otherwise in cases where paragraphs contained fixed expressions or idioms, the direct translation strategy failed in transmitting the same meaning or message of TL to SL. Students who have used the direct translation strategy in cultural translation (the translation of idioms, fixed expressions) have produced a noncoherent translation, as well as in such cases there were examples of complete cultural losses.

Borrowing as a translation strategy has been used by students only in cases of Albanian cultural word translation where there was no equivalence in SL. Even though in some specific cases students overused the borrowing translation strategy, which lead translation to become non-coherent as well as meaningless.

Lastly, omission has been used in specific situations in which students did not find any equivalent word in English, or in cases where they did not understand the meaning of source words.

Challenges that students have faced during the translation of three Albanian literary texts have been related to translation of Albanian cultural words, Albanian idioms, Albanian fixed expressions, as well as the adjustment of optative which lacks in English language. Students, themselves, declared that there are vast differences amongst these two languages which caused them many challenges or 
difficulties during such translations. Albanian language has a very complex structure of grammar which differs a lot from English language, as well as its culture, which mostly corresponds as nonequivalent to English language as a target language. All challenges or difficulties that student have stated correspond to the mistakes that they have made in their translations, but generally the biggest challenges for them have been in finding equivalent words due to translation of Albanian cultural words, idioms and expressions as well as the adjustment of optative verb mood in English language.

Regarding recommendations, for solving or facing such difficulties or challenges, that students have declared themselves are similar to their stated solutions which they have given in their questionnaire.

Actually, the literary text translation can be considered as one of the most complicated translations, since it requires an art or a talent for doing it. Despite the fact that students who translated such Albanian literary texts have been undergraduate participants, and cannot be considered as professional translators, they have still have given a huge commitment to the research.

Based on the mistakes or problems that have been identified on their translations it can be recommended that:

1. Students who deal with Albanian literary translation should have previous experience in reading Albanian literature

2. Students should have a background knowledge of the source text before translation

3. Students should read and reread a text before starting to translate

4. Students should use Albanian-Albanian dictionary if they deal with Albanian literary translation

5. Students should use the direct translation strategy only in sentences that contain equivalent words in English language

6. Students while using borrowing as translation strategy should give an explanation to such words

7. Students should use omission as translation strategy only when the omitted word in SL does not impact the meaning of TL

8. Students may use the conceptual metaphor in literary text translation in order to make the translation more artistic and figurative one

9. Students should adjust the optative verb mood in English language by the addition of English interjections or by the addition of the modal verb "may"

10. Students may adjust the subjunctive Albanian verb mood by using the past simple of indicative verb mood in English language

11. Students who try to translate idioms or fixed expressions of SL into TL may shift them into non-literary translation when there is no equivalence to TL or they may find an equivalent one in TL even though it might have a complete different structure of words

12. Students should take care to the implementation of coherence in TL, rather than focusing in cohesion

13. Students should take into consideration that the addition of sentence elements such as the "subject" in English language makes translation meaningful and coherent

14. Students should bear in mind that such literary text translations require great efforts, hard work and a skill in realising it, and none of them, who do not have a general background on cultural translation, can ever realise it in the best way possible.

\section{References}

"Amanet" (n.d).In Fjalor shqip. Retrieved from https://fjale.al/amanet

Baker, M. (2017). In other words: A coursebook on translation (3rd ed.). London and New York: Routledge). 13. Schulte, R. and Biguenet, J. (Original work published 1992).

Baker, M. (2018). In other words: A course book on translation (3rd ed.). London and New York: Routledge). 13. Schulte, R. and Biguenet, J. (Original work published 1992). 
Baker, M. \& Saldanha, G. (1998/2009). Routledge Encyclopedia of translation studies. Published in the USA and Canada by Routledge 270 Madison Ave, New York, NY 10016.

Cambridge Dictionary. (n.d). "To catch someone red-handed”. In Cambridge Dictionary.Retrieved fromhttps://dictionary.cambridge.org/dictionary/english/red-handed

Çeliku, A. (2005). Koherenca tekstore: Hyrje në conceptet bazë të gjuhësisë së tekstit nëpërmjet një qasjeje krahasuese të shqipes me gjermanishten. Shkup: Alfa print.

Çeliku. A. (2013). Realization of text coherence in English and Albanian languages through conceptual metaphor. Research on Humanities and Social sciences. Retrieved from https://www.slideshare.net/AlexanderDecker /realisation-of-text-coherence-in-english-and-albanian-languages-through-conceptual-metaphors-27916034

Daniel, M., Dobrushina, N. \& Ganenkov, D. (2019). The Mehweb language: Essays on phonology, morphology and syntax. Berlin: Language Science Press. $\mathrm{xv}+341 \mathrm{pp}$.

Fernando, C. \& R. Flavell. (1981) On Idiom: Critical Views and Perspectives. Exeter Lingusitic Studies. Vol. 5., pp.194. Exeter.

Gaba, A. (2018). Comparative Analysis of English and Albanian Body Idioms. International Journal of Humanities Social Sciences and Education (IJHSSE), vol 5, no. 3, 2018, pp. 184-196. Retrieved from https://www.arcjournals.org/pdfs/ijhsse/v5-i3/19.pdf

Gibová, K. Bednárová. (2014). The dark side of literary translation: an analysis of translation trainees' performance. Semantic Schoolar, Corpus ID: 207900980. Retrieved from https://www.pulib.sk/web/kniznica/elpub/ dokument/Kacmarova5/subor/Gibova.pdf

Guerra, F. A. (2012). Translating culture: problems, strategies, and practical realities. Sic-a journal of literature, culture, and literary translation. ISSN 1847-7755; Doi: 10.15291/sic/1.3.1 Retrieved from https://www.sicjournal.org/ArticleView.aspx?aid=173

Jakobson, R. (1960). Linguistics and poetics' in T Sebeok (ed.), Style in language, Massachusetts Institute of Technology Press, Cambridge, Mass.

Koça, S. \& Jashari, A. (2013). Comprehension and Interpretation of English and Albanian Fixed Expressions. Academic Journal of Interdisciplinary Studies. Vol 2, No 8, DOI: 10.5901/ajis.2013.v2n8p319. Retrieved from https://www.mcser.org/journal/index.php/ajis/article/view/740

Kövecses, Zoltán. “Conceptual Metaphor Theory.” In The Routledge Handbook of Metaphor and Language, edited by Elena Semino and Zsófia Demjén, 13-27. Abingdon: Routledge, 2017.

Lakoff, G. \& Johnson, M. (2003). Metaphors we live by. The University of Chicago Press, Chicago, 6o637 The University of Chicago Press, Ltd., London

Newmark, P. (1988). Approaches to Translation. Shanghai Foreign Language Education Press.

Newmark, P.P. (1995). A correlative approach to translation. Madrid: Editorial Complutense.

Nida, Eugene A and Charles R. Taber (1982). The Theory and Practice of Translation. Leiden: E.J. Brill.

Poshi \& Lacka. (2016). Strategies in translating idioms and fixed expressions from English into Albanian. BJES, September 2016, Vol. 12, pp. 25-60. ISSN 2310-5402 (Online). Retrieved from http://bjes.beder.edu.al/uploads/arch-201611301616512804.pdf

Qesku, P. (200o), Fjalor Anglisht - Shqip, Tiranë, Botimet TOENA

Shojaei, A. Translation of Idioms and Fixed Expressions: Strategies and Difficulties, Theory and Practice in Language Studies, Vol. 2, No. 6, pp. 1220-1229, June 2012; http://www.academypublication.com/issues /past/tpls/volo2/o6/18.pdf

Siefring, J. (2004), Oxford Dictionary of idioms, Second Edition, Oxford University Press.

Simpson, J., Speake, J. (2003), The Concise Oxford Dictionary of Proverbs, Oxford University Press

Soanes, C. and Stevenson A. (2004), The Concise Oxford English Dictionary, Eleventh Edition, Oxford University Press

Spears, R. A. (2005) Dictionary of American Idioms and Phrasal Verbs, The McGraw Hill Companies, USA

Stefanllari, I. (1998), Fjalor frazeologjik anglisht-shqip, Shtëpia Botuese Enciklopedike, Tiranë.

Tanku, P. (2013). Overview of Translation Process and Equivalence in Albanian Literary Translations. Academic Journal of Interdisciplinary Studies, Vol.2 No 4. Retrieved from http://www.mcser.org/journal/index.php/ ajis/article/view/126

Vega-Moreno, R. (2003), 'Relevance Theors and the construction of idiom meaning', UCL Working Papers in Linguistics 15, https://www.ucl.ac.uk/pals/research/ linguistics/ publications/ wpl/ o3papers/rosa

Vinay, J.P. and J. Darbelnet (1995). Comparative Stylistics of French and English: A Methodology for Translation, translated by J. C. Sager and M. J. Hamel, Amsterdam / Philadelphia: John Benjamins. 